\title{
Information as a Tool for Effective Management
}

\author{
${ }^{1}$ Bolanle Clifford Ishola, CLN, ${ }^{2}$ Rhoda Ose Isiwele-Ishola \\ ${ }^{I}$ Ag. University Librarian, OduduwaUniversity,Ipetumodu P.M.B. 5533 Ile-Ife, OsunState.Nigeria \\ ${ }^{2}$ Library and Information Science Department, Faculty of Education, University of Ibadan.
}

\begin{abstract}
The concern of this research was information as a tool for effective management .Objective of study was to: point out the importance of information in management; encourage managers to make judicious use of information in the whole process of management and to add to the existing body of knowledge. Ambrose Alli university library and Registry provided the data for the study. The survey research method was used for the study and the major findings were that;information is a useful and indispensable tool in the management process; the respondents agreed they often need information for effective management in all areas; the respondents often visit information centers and information sources are available that they depend on for their information needs;information has a positive effect on management and the major problem in management is the lack of information and in trying to meet their information needs, the major problem is fund and timely information. The study recommended inter alia that: more funds should be allocated to libraries and information centers to acquire more current information materials and Managers should not depends only on the information centers immediately close to them. They should also try and visit other centers even afar. In that case, they will be exposed to more and more information. Similarly, Mangers should embrace information communication technology in all ramifications and incorporate it into every aspect of their activities.
\end{abstract}

Keywords: Information; information as a tool; effective management

\section{Background to the study}

\section{Introduction}

This study, among other things seeks to appraise the importance of information as a tool that engenders effective management. Fayol (1949) stated that management comprises of six major elements which are:

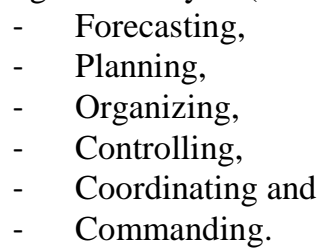

Furthermore, he submitted that there is more to management than mere gut feeling. In performing these six major elements, adequate information is needed to function well in any of the areas concerned. This means that information in a very vital and important tool in management and without its use, adequacy and appropriateness will be lacking in the process of management. According to him, as long as man lives, he needs and will continue to need information in his everyday activities. A well organized system of information is a prerequisite for effective decision making. Consequently the possession or awareness and use of appropriate information ensures managerial functioning knowing that the major function is to increase the knowledge of the user, reduce his level of uncertainty and reduce the variety of choices available to him. Not only does information have a special meaning to the manager, it is also extremely complex.

The world presently is undergoing an information revolution, a time when the world's development has accepted information as a valuable resource. Mintzbery (1973) includes information as one of the managerial roles. He stated that the information roles incorporates monitoring, filtering and disseminating information as common if not a universal part of managerial work. Further, he stated that a manager's unique access to information and his special and authority places him at the central point in the system which makes significant and strategic organization decision. Oshiotse (1993) stated that all the human activities results in the communication which in his context means information. Most establishments or institutions are planted to perform specific roles in the economy. To achieve these objectives, the management of such bodies must be near hundred percent efficient. That expected high level of efficiency in management of such bodies depend on a fine functional information base and information flow methods. Ononogbo (1990) stated that the technologies for recording information range from clay tablets in ancient Mesopotamia through papyrus and parchment to wax and paper. This means that information and the technology for collecting, processing, storing and 
disseminating it are probably as old as man himself. Thus when people talk about information and communication technology (ICT), they are referring to the modern concept of the subject (information).

Drucker (1995) stated that most managers still need to learn how to use data and take responsibility of information. According to him, few managers know how to use relevant questions rating from "what information do I need to do my job", "when do I need it", "in what form" and "from where should I get it". In his questions, he necessitated information in management.

One becomes aware of a circumstance through information disseminated and received. Thus, knowledge is a product of information and does not exist in vacuum. Information is a unique and crucial source of living without which human life may be heading for isolation. Information as a social prerequisite for living can be perceived in terms of its everyday sense of facts, data, opinion and the likes including but certainly not confined to what is revealed in the reality of research and scholarship in all fields of knowledge.

If we accept information as a valuable resource, it is thus, amenable to macro and micro economics principles which cannot be overlooked. In formulating national development policies, we must look at the level of demand and supply of information, the part it plays in management and its utility. According to Aiyepeku (1989), policy makers and implementers in Nigeria have need for information for decision making and planning. He however decries the proportion of hard information to propaganda and public enlightenment. He affirmed that systems dealing with directive information are identical to statistical information systems which deal with analysis and presentation of statistical data. The importance of these statistical information have led to the establishment of data banks in Nigeria while the need for operative information led to the establishment of the defunct National information and documentation centre in the National Library of Nigeria in order to actualize their mission, these organizations and the total information infrastructure.

Olaisen (1990) states that management information systems and information resource management both reflect the information needs and complex integrated and discriminatory systems for providing managers with data and information needed for managing organizations in circumstances of change and turbulence. Large enterprises today are looking for

- Ways to improve at all levels of management.

- Customer requirement for quality which has increased the need to motivate employers with greater

- Awareness of the meaning of their jobs.

This means that the information systems must be designed to give information that can be systematized to offer core services so that the information systems and networking can be seen as corners in a triangle that covers the strategic shape of the companies to come. This calls for information processing with the aim of moving information among individuals and groups in organizations or government in order to co-ordinate work. Research has shown that information can be used to achieve strategic managerial objectives in the following different ways:

- They can be used to achieve greater differences in existing operations.

- They can be used to improve the strategic planning process.

- They can be used to open new markets. Information can add value to services and products and throw competitors off balance. Such information is usually from different sources as will be shown later in this study.

As no man is an Island to himself, information has come to stay as a major source in the enhancement of effective management as suggested by the subject under review. Olusola (2006) stated that one of the essential requirements of making a business grow over time in the existence of a documented record of every transaction the business undertakes. Furthermore, he stated that every business either big or small deserves a record on how it expands and the money it generates. Such a record is a memory of the business. That is, the information house of the business in question. He stated that the benefits of keeping records cannot be overemphasized and principal defect of not keeping business record is that it robs the manager or entrepreneur of the benefit of having a comprehensive understanding of the business trend, since the records will entail both the business is fairing. He emphasizes the importance and indispensability of information in business, there by stating that information is an essential tool in the achievement of a proper business management.

\section{Statement Of The Problem}

Managers are faced with different information needs which in one way or the other needs to be satisfied. The information needs of managers which are of paramount importance to this research is that relevant to decision making which is an important aspect of management. Such needed information can be got from different sources ranging from books, journals, newsletters to conferences, seminars, workshops and so on. It is observed that most managers do not even participate in such enlightening activities or even visit the library which is one of the most important sources of information that would be of immense help in terms of 
broadening their knowledge and enabling them to make proper decision that will be of great benefit to management in general.

This study is therefore going to show the importance of information as a tool for effective management and also to give the managers awareness as to where and how these needed information are seen.

\section{Objectives of the study}

This research is specially designed to achieve the following

- Point out the importance of information in management.

- Find out the various centers and sources of information that will be of immense use to managers.

- Encourage managers to make judicious use of information in the whole process of management

- Lastly, to add to the already existing body of knowledge.

\section{Research Questions}

i. Does the presence of information enhance an effective management?

ii. What role does information play in management?

iii. What area is information most frequently needed in the process of management.

iv. Does the lack of information have any negative effect on management?

v. What are some of the obstacles to free flow of information?

\section{Significance of the study}

The significance of this research is to provide managers with the relevant information which will enable them to make wise information search. This search will in turn be of great benefit to them (managers) in the process of management. It will also help among other thing highlight the information needs of managers, where and how there information are searched for and also found.

The entire populace will also in one way or the other benefit from research. This is so in the sense that in area of management or the other, they are involved, whether it be academic, business or community management. Lastly, the research will be of immense help to researchers who may wish to carry out further investigation to related problems.

\section{Literature Review}

Managers are faced with different information needs which in one way or the other they want satisfied. As stated by Oshiotse (1993), all the human activities that result in the production of goods and service depend on effective communication. Olaisen (1990) sated that management information systems and information resources management both reflect the information needs and complex integrated and discriminatory system for providing managers with data and information needed for managing organization in circumstances of change and turbulence. According to Curas (1987) man needs and will continue to need information as much as water, air or fire in order to develop. The flow of information and its use are of central importance in management. In the management process, the information that managers read or hear about management can have an important impact in the process of management.

Managers need information for the following different purposes. Decision making: According to Abel (2004) information leads to better decision making by managers. He stated that it engenders growth and development and erroneous conceptions, views and opinions on programmes and activities if institutions and organizations are corrected when information I properly disseminated. Cyert et al (1956) implied that management is a series of decision making process and asserted that decision making is at the heart of effective activity in business. He stated that decision should be made fast especially in the current context where the most precious and least manageable commodity available to man is time. No man is self-sufficient when it comes to the use of information. The managers are no exemptions. No matter how educated they may be, they still need and will continue to need information for proper decision making. According to Opeke (1993) information has now been universally accepted as a vital tool in any organization. A well-organized system of information is a prerequisite for effective decision making. Aiyekpeku (1978) stated that efficient decision making is a function of the amount of timeliness, accuracy of useful information utilized in the process. If information is received and never applied to subsequent decision, its effect does not exist and it cannot be measured. Consequently, the possession or awareness and use of appropriate information ensure organizational functioning.

Acquisition of knowledge: According to Opeke (1993) the major function of information is to increase the knowledge of the user, reduce the level of choices available to him. In a further sense, he submitted that to be effective, information must be accurate, timely and relevant. He stated that by the term accuracy, he means that the information should be free from bias, manipulations and distortion, it is clear and accurately reflects the 
meaning of the data on which it is based. Timelines simply means that the recipient can get information when they need it. Information is therefore crucial to the manager. Not only does information have special meaning to him, it is also extremely complex. Whatever their roles, managers need information for the possession of relevant knowledge.

Managerial Aspiration: The managers need information to satisfy their desires and aspire in the management process. According to Olusola (2006) one of the essential requirements of making a business grow over time is the existence of a document record of every transaction, the business either big or small deserves a good record of how much it expends. Such a record is the memory of the business. Furthermore, he stated that the principal defect of keeping business record is that it robs the entrepreneur of the business tend. In such a case he cannot aspire higher. He stated that when the entrepreneur possesses a good record of his transactions in business, it becomes like a compass which guides him on the direction where his resources are invested.

Awareness: Managers need about the current trends in the society to help them manage properly and solve poor management problems. Opeke (1991) stated that information reduces uncertainty, increases awareness, that is, it has the ability to answer question and clarify situations. Therefore a manager who knows the right question to ask will more likely receive the needed information for his decision making. In this age information is available, mostly in an unorganized form; a manager needs to ask the right question in order to get the right answers. Information is an important and powerful force to reckon with in management as man needs and will continue to need information in his everyday activities in order to develop.

Stonier (1991) highlighted the importance of information when he stated that information is the most important factor in the modern production system as opposed to land, labour and capital. His reason was that man could reduce the requirement of land, labour and capital. Furthermore, he stated that information has become an indispensable resource for research and development activities. In fact every activity involving the use of human, material and financial resources requires for the elaborate use of information for the realization of the set goals and objectives. Information is crucial source of living without which human life may be heading for crisis and isolation. Aigbiremoh (2004) stated that a nugget of relevant, precise and timely information could exert tremendous influence on the behavior of individuals and their activities. Opeke (1998) has it that information has now been universally accepted as a very vital resource in any organization. A well organized system of information is a prerequisite for effective decision making. Consequently, the possession or awareness and use of appropriate information ensure organizational functioning. The major function of information is to increase the knowledge of the user, to reduce his level of uncertainty and reduce the variety of choices available to him. Furthermore, he argued that information plays a vital role in management. Better information result in better public decisions. While proceeding, he stated that information also affects the way in which public employees work within the management process because majority of the public employees want to be seen to have done a good job and gain a sense of satisfaction from a job properly carried out. Information that allows them to compare actual result with planned results is essential and desirable. According to him, better information is a prerequisite for meaningful citizen involvement in the process of governance. Information permits media reporters to analyze and evaluate how well a government is performing, thus facilitating efforts to inform the public. According to Gbadamosi (2005) information is a vital resource in all creams of professionals though the information requirements various professionals differs. The information is described as a prerequisite for effective decision making and consequently the awareness and use of appropriate information ensures organizational functioning

\section{Survey method}

\section{Methodology}

The social survey research method was adopted in carrying out this research. This is because it covers all areas and disciplines of different information. The social survey methods is the most widely used when the study concerns a large population. According to Ifidon and Ifidon (2007), the survey research method gathers data from members of a population in order to determine the current status of the population with respect to one or more variables. Furthermore, they stated that it is not concerned with individual as entities but with the generalized statistics that emanate when data are abstracted from a number of individual cases. It was designed to elicit some vital and crucial information from managers.

\section{Population and Sample of the study}

The population for this study is managers in general. Due to the fact that it was not possible to go round all managers, two organizations were used in carrying out this research. These organizations are Ambrose Alli University Library and the Registry Department of the University. Only the staff of those two organizations in managerial positions was used as the population for the study. Since the staff were not too many, all of them instead of a simple were used. The administered were completed and returned. 


\section{Sources of Data}

The constituents of the sources of data were questionnaires which were supplemented by the interview technique. The review of related literatures also formed a base for the sources of data in this study.

\section{Questionaires}

\section{Data Collection Instruments}

Some needed information that are very vital to this research were collected through the use of questionnaires. These questionnaires were designed to appraise the importance of information to management and to determine the extent to which information can enhance the management process and managerial effectiveness. Twenty four copies of the questionnaires were personally administered to the selected population for the study. Twenty copies of the questionnaire were duly completed and returned.

The questionnaire method was adopted due to the following reasons:

i. The questionnaire method gives room for uniformity from one measurement situation to another.

ii. It gives room for facts to be gathered in many situations from the managers.

iii. It could easily reach the targeted population concerned.

iv. Respondents have a lot of confidence when they are treated anonymously.

v. There are good chances of giving valid and reliable answers which may not be possible with other methods such as interview.

vi. Respondent could at their own convenient time complete the questionnaire given to them.

vii. The questionnaire method was supplemented by interview technique.

\section{Interview}

Another data collection instrument for this study was that personal interview schedule. This was used because it enabled the researcher to explain a few questions that seems complex which might have discourage a thoughtful response to the questionnaires that were earlier administered. It also afforded the researcher the opportunity of seeking for clarification on answer provided on the questionnaires.

\section{Methods of Data Analysis}

The completed and returned questionnaires were analyzed. The method of analysis was by the use of tables and percentages. After the questionnaires were collected, they were analyzed with each item represented in a tabular form. Each table displayed the numbers of respondents and their responses to each question.

\section{Analysis Of Data And Presentation Of Results}

Table .1: Analysis of Response rates.

This table shows the response rate

\begin{tabular}{|l|l|l|}
\hline Items & Frequency & Percentages \\
\hline No sent & 24 & $100 \%$ \\
\hline No received & 20 & $83.3 \%$ \\
\hline Total & 20 & $83.3 \%$ \\
\hline
\end{tabular}

Table 2: Is information required for effective management?

\begin{tabular}{|l|c|c|}
\hline $\begin{array}{l}\text { Is information required for effective } \\
\text { management? }\end{array}$ & Responses & Percentages \\
\hline Yes & 20 & $100 \%$ \\
\hline No & - & $100 \%$ \\
\hline Total & & \\
\hline
\end{tabular}

All the respondents are of the opinion that information is required if an effective management must be achieved.

Table. 3. How useful?

\begin{tabular}{|l|c|l|}
\hline How useful & Responses & Percentages \\
\hline Useful & - & - \\
\hline Very useful & 10 & $50 \%$ \\
\hline Indispensable & 10 & $50 \%$ \\
\hline Total & 20 & $100 \%$ \\
\hline
\end{tabular}

As indicated on table $3,10(50 \%)$ of the respondents are of the opinion that information is indispensable in management while $10(50 \%)$ of the respondents are of the opinion that information is very useful to management. 
Table 4: result between information and management?

\begin{tabular}{|l|c|c|}
\hline $\begin{array}{l}\text { Is there a result between information and } \\
\text { management? }\end{array}$ & Responses & Percentages \\
\hline Partially & 2 & $10 \%$ \\
\hline Yes & 18 & $90 \%$ \\
\hline No & - & - \\
\hline \multicolumn{1}{|c|}{ Total } & 20 & $100 \%$ \\
\hline
\end{tabular}

Majority of the respondents $18(90 \%)$ are of the opinion that there is a result between information and management and $2(10 \%)$ of the respondents are of the opinion that there is a partial result between information and management.

Table 5: Is information often needed in management?

\begin{tabular}{|c|c|c|}
\hline $\begin{array}{l}\text { Is information often needed in } \\
\text { management? }\end{array}$ & Responses Percentages \\
\hline Yes & 20 & $100 \%$ \\
\hline No & - & - \\
\hline Total & 20 & $100 \%$ \\
\hline
\end{tabular}

$20(100 \%)$ of the respondents are of the view that information is often needed in management.

Table 6: if the use of information can enhances effective management?

\begin{tabular}{|c|c|c|}
\hline $\begin{array}{l}\text { If the use of information enhance } \\
\text { effective management? }\end{array}$ & Responses & Percentages \\
\hline Yes & 20 & $100 \%$ \\
\hline No & - & - \\
\hline Total & 20 & $100 \%$ \\
\hline
\end{tabular}

From table 6 above, there is a clear indication that information enhances an effective management. This is drawn from the $100 \%$ response rate.

Table 7: Does the lack of information have any negative effect on management?

\begin{tabular}{|l|c|c|}
\hline $\begin{array}{l}\text { Does the lack of information have any } \\
\text { negative effect on management? }\end{array}$ & Responses & Percentages \\
\hline Yes & 20 & $100 \%$ \\
\hline No & - & - \\
\hline \multicolumn{1}{|c|}{ Total } & & $100 \%$ \\
\hline
\end{tabular}

Table 7 shows that $20(100 \%)$ of the respondents agreed that the lack of information has a negative effect on management.

Table 8: How does information influence your management process?

\begin{tabular}{|l|c|c|}
\hline $\begin{array}{l}\text { How does information influence your } \\
\text { management process? }\end{array}$ & Responses & Percentages \\
\hline Positively & 20 & $100 \%$ \\
\hline Negatively & - & - \\
\hline Total & 20 & $100 \%$ \\
\hline
\end{tabular}

Table 8 shows that the presence of information has a positive influence on management.

Table 9: aspect of management where information is mostly needed.

\begin{tabular}{|l|c|c|}
\hline $\begin{array}{l}\text { Aspect of management where information is } \\
\text { mostly needed. }\end{array}$ & Responses & Percentages \\
\hline Controlling & - & - \\
\hline Coordinating & 1 & $5 \%$ \\
\hline Planning & 10 & $50 \%$ \\
\hline Organization & 1 & $5 \%$ \\
\hline Others (All) & 7 & $35 \%$ \\
\hline Total & 19 & $95 \%$ \\
\hline
\end{tabular}

On table $9,1(5 \%)$ of the respondents is of the opinion that information is mostly needed in the area of co-ordination, $1(5 \%)$ stated that it is mostly needed in the area of organizing, $10(50 \%)$ are of the view it is mostly needed in the area of planning, 7 (35\%) stated that it is needed in all areas lettered A - D and $1(5 \%)$ was silent about the question. 
Table 10: Does management depend fully on information?

\begin{tabular}{|l|c|c|c|}
\hline $\begin{array}{l}\text { Does management depend fully on } \\
\text { information }\end{array}$ & Responses & Percentages \\
\hline Yes & 18 & $90 \%$ \\
\hline No Total & 2 & $10 \%$ \\
\hline \multicolumn{2}{|l|}{20} & $100 \%$ \\
\hline
\end{tabular}

$18(90 \%)$ of the respondents agreed that management depends fully on information while $2(10 \%)$ are of the opinion that management does not fully depend on information.

Table 11: Does the lack of information hinder effective management?

\begin{tabular}{|l|c|c|}
\hline $\begin{array}{l}\text { Does lack of information hinder effective } \\
\text { management? }\end{array}$ & Responses & Percentages \\
\hline Yes & 20 & $100 \%$ \\
\hline No & - & - \\
\hline Undecided & - & - \\
\hline \multicolumn{1}{|c|}{ Total } & 20 & $100 \%$ \\
\hline
\end{tabular}

Drawing from table 11, all the respondents are of the view that lack of information hinder effective management.

Table 12. Do you have some information sources you depend on?

\begin{tabular}{|l|c|c|}
\hline $\begin{array}{l}\text { Do you have some information sources you } \\
\text { depend on? }\end{array}$ & Responses & Percentages \\
\hline Yes & 19 & $95 \%$ \\
\hline No & 1 & $5 \%$ \\
\hline Total & 20 & $100 \%$ \\
\hline
\end{tabular}

According to table 12 above, 19 (95\%) of the respondents have some information sources which they depend on for their information needs while $1(5 \%)$ started that he does not have any information source.

Table 13: Reliability of information sources?

\begin{tabular}{|c|c|c|}
\hline Are your sources of information reliable? & Responses & Percentages \\
\hline Yes & 18 & $90 \%$ \\
\hline No & 1 & $5 \%$ \\
\hline Total & 19 & $95 \%$ \\
\hline
\end{tabular}

From the table above $13(90 \%)$ of the respondents admitted that they have some information sources which they depend on for their information needs. $1(5 \%)$ stated that he does not have any sources of information $1(5 \%)$ however, did not respond to the question.

Table 14: Do you often visit information centres?

\begin{tabular}{|l|c|c|}
\hline Do you often visit information centres? & Responses & Percentages \\
\hline Yes & 19 & $95 \%$ \\
\hline No & 1 & $5 \%$ \\
\hline Total & 20 & $100 \%$ \\
\hline
\end{tabular}

From the table 14 above, 19 (95\%) of the respondents are of the opinion that they often visit information centres. $1(5 \%)$ however alleged that he does not visit any Information centre.

Table 15: Amount of information available.

\begin{tabular}{|l|c|c|}
\hline Amount of available information & Responses & Percentage \\
\hline Sufficient & 7 & $35 \%$ \\
\hline Fairly sufficient & 12 & $60 \%$ \\
\hline Insufficient & 1 & $5 \%$ \\
\hline \multicolumn{1}{|c|}{ Total } & 20 & $100 \%$ \\
\hline
\end{tabular}

From the gathering on the table 15, 7 (35\%) of the respondents stated that the amount of information available to them is sufficient. $12(60 \%)$ stated that the amount of information available to them is fairly sufficient and $1(5 \%)$ indicated that the amount of available information is not sufficient. 
Table 16: major problem in management.

\begin{tabular}{|l|c|c|}
\hline Major problem in management & Responses & Percentages \\
\hline Lack of information & 9 & $45 \%$ \\
\hline Lack of time & 7 & $35 \%$ \\
\hline Too many choices & 2 & $10 \%$ \\
\hline Others & 2 & $10 \%$ \\
\hline \multicolumn{1}{|c|}{ Total } & 20 & $100 \%$ \\
\hline
\end{tabular}

As indicated in table 16 above, $9(45 \%)$ of the respondents stated that the major problem in management is lack of information. $7(35 \%)$ are of the opinion that it is lack of time. $2(10 \%)$ stated that the major problem of management is too many choices of information. One of the respondents however stated that the major problem is a combination of lack of time and lack of information is effective management of available information.

Table 17: Problems encountered in trying to meet information needs?

\begin{tabular}{|l|c|c|}
\hline $\begin{array}{l}\text { Problems encountered in trying to meet } \\
\text { information needs? }\end{array}$ & Responses & Percentages \\
\hline Lack of information materials & 3 & $15 \%$ \\
\hline Lack of time & 2 & $10 \%$ \\
\hline Lack of fund & 11 & $55 \%$ \\
\hline Others & 4 & $20 \%$ \\
\hline \multicolumn{1}{|c|}{ Total } & 20 & $100 \%$ \\
\hline
\end{tabular}

As stated by $3(15 \%)$ of the respondents, lack of information materials is the problem encountered in trying to meet their information needs. $2(10 \%)$ sees lack of time as the problem. $11(55 \%)$ stated that lack of fund is the problem encountered in trying to meet their information needs while $4(20 \%)$ indicated that the combination of lack information materials and lack of fund is the problem encountered.

\section{Discussion Of Findings And Presentation Of Results}

The findings from the responses given by the respondents are as follows:

i. All the respondents agreed that information is required if an effective management must be achieved. It is therefore evident that information is a useful and an indispensable tool in the management process.

ii. The $90 \%$ response rate that there is extra success rate when management is carried out with information goes to confirm the words of stonier (1991) that information is the most important factor in the modern production as opposed to land, labour and capital.

iii. The use of information in management is totally unavoidable. This is drawn from the $100 \%$ response rate that information is often needed in management and the $100 \%$ response that the use of information can enhance an effective management.

iv. All the respondents are of the opinion that the lack of information has a negative effect on management. This goes a long way to show the extent to which information is a veritable tool for effective management.

v. From the $100 \%$ response rate that information has a positive influence that if there is no information, there can be no positivity in management.

vi. Responses to the question on areas where information is mostly needed in management, shows that in all aspects of management, information is always needed to succeed. Without information, decision cannot be taken on the next line of action.

vii. Judging from the response rate that management depends fully on information, there is a clear indication that information is a catalyst in management. The lack of it is a major slow down to management.

viii. $\quad 90 \%$ stated that they depend on some information sources for their information needs and the same $90 \%$ are of the view that their sources are reliable.

ix. With $90 \%$ response rate that the respondents often visit information centers and that the amount of information available to them are sufficient, there is an implication information is being sought after to manage effectively.

x. Judging from the percentage of the response rate, the major problem in management is lack of information and in trying to meet such information needs, the major problem is lack of fund to get adequate and timely information.

xi. Information is needed a veritable tool for effective management, however other factors such as fund, human factor and environment cannot be ignored. 


\section{Conclusions}

We are in a world where everyone needs information to remain relevant in the scheme of things; Information has become a veritable and indispensable tool in whatever one embarks on in life. Therefore, man needs and will continue to need information in every aspect of his life. Arising from this is the quest and relevant hunger for information.

At all levels of management, information is instrumental for better performance. In the same veil, it supports the highest stands of proper and meaningful management. This makes it possible to arrive at meaningful results. Majority of those who are successful in the managerial world are those who make judicious use of available information and seek for those information that are not immediately available, where necessary. Information is a major complement to the efforts of managers. It is therefore proper to say that poor results that emerge as a result of poor management is a function of managing without timely and accurate information.

Ignorance is said to be a disease. Therefore, the first step in man's endeavour to eliminate the disease called ignorance is to adequately be informed in the right place and the right time. Information makes the world go round as it reduces the level of man's uncertainly and increases his level of knowledge. However, the findings in this study show that the poor management state has to do with the lack of use information in management.

\section{Recommendations}

The following recommendations are proffered by the researcher for consideration guided by the emergence of this study:

i. There should be a general orientation to draw the attention of managers to see how effectively they can manage with the use of information.

ii. Information centers should be brought closer to be at the easy access of every one rather than locating them in some selected areas access the country.

iii. Huge amount of fund should be allocated to libraries and information centers to acquire more current information materials.

iv. Managers should not depend only on the information centers immediately close to them. They should also try and visit other centers even afar. In that case, they will be exposed to more and more information.

v. Managers should also be made to understand to the future of management without timely and relevant information and the shortfalls that abound as a result of lack of information.

vi. Seminars and conferences should be held to teach managers to develop reading habits thereby gaining access to information.

vii. Mangers should embrace information communication technology in all ramification

\section{Suggestion for Further Study}

The following topics are proposed for further research to bridge whatever gaps may exist in this study:

i. The consequences of management without information in Nigeria.

ii. Planning without information.

[1]. Abel, A.K (2004). The role of information in management of local government in Nigeria,

Owena journal of library and information science.1 (1). 41-48

[2]. Aigbiremoh,m.o (2004), understanding the use of library: users guide. Ibadan: stirling horden publications

[3]. Buckland, m (1991).Information and information system. New york; pager.

[4]. Curras, E.(1987). Information as the fourth vital element and its influence on the culture of the people. Journal of information science.13 (3).23-40.

[5]. Cyert, R.M. et al (1965). Observation of a business decision. Journal of business.24(4).237-248

[6]. Drucker, P.(1995). Managing in time of great change. Oxford: Butterworth Heinemann.

[7]. Gbadamosi, B.O.(2005). Comparative study of information requirement seeking strategies and utilization of education administration and medical doctors in oyo state, Nigeria. Owena journal of library and information science.2 (1). 10-21

[8]. Ifidon, S.E .(2006). Planning without information: the bane of national development.26 inaugural lecture in Amnrose Alli University, Ekpoma. Delivered on $29^{\text {th }}$ June 2006.

[9]. Ifidon,S.E And Ifidon, E.I (2007). Basic principles of research methods. Benin city: good news express communications.

[10]. Mintzberg, H . (1993). The nature of managerial work. New york: harper Collins.

[11]. Nwankwor,J.I (1985) fundamentals of management information system. Ibadan: spectrum.

[12]. Olaisen, J.(1990). Information resources management as a critical success factor in northern banks and insurance companies: information management practice and education proceedings of the international serminar.budapest.24 $4^{\text {th }}-27^{\text {th }}$ april.410-431.

[13]. Olusola, S. (2006).Imperatives of keeping records. Saturday Tribune, $7^{\text {th }}$ October, 2006.pp 9.

[14]. Opeke. R.(1993)The public relations department of local government: ensuring adequate, accurate and effective information dissemination to the public. University of Ibadan. Department of Library, Archival and Information Studies. Papers Presented at the Workshop on Information Management.

[15]. Saunders, W.I.(1980), information the "unscarce"' resource in the nationwide provision and use of information. ASLIB, 115, la.jointconference. $15^{\text {th }}-19^{\text {th }}$ September.Sheffield proceedings. London: the library association.pp. 2

[16]. Stonier, T. (1991).Towards a new theory of information. Journal of information science. Journal of Information Science.17 (5).257263. 